\title{
Interference-Aware Routing in Wireless Multihop Networks
}

\section{Doctoral Thesis}

Author(s):

Parissidis, Georgios

Publication date:

2008

Permanent link:

https://doi.org/10.3929/ethz-a-005673824

Rights / license:

In Copyright - Non-Commercial Use Permitted 
DISS. ETH NO. 17737

\section{INTERFERENCE-AWARE ROUTING IN WIRELESS MULTIHOP NETWORKS}

A dissertation submitted to

ETH ZURICH

for the degree of

Doctor of Sciences

presented by

Georgios PARIssidis

M.Eng. TUC Greece, DEA Université Paris VI

date of birth

January 13, 1977

citizen of

Greece

accepted on the recommendation of

Prof. Dr. Bernhard Plattner, examiner

Prof. Dr. Gunnar Karlsson, co-examiner

Prof. Dr. Peter Steenkiste, co-examiner 



\section{Abstract}

Nowadays, wireless multihop networks, providing mesh connectivity emerge as alternative network infrastructure for numerous applications such as shared broadband Internet access, monitoring for emergency, medical and security reasons, distributed backup and multimedia applications. Since these networks are highly decentralized and self-organized, routing becomes a critical factor for their performance and efficiency.

The work in this thesis focuses on interference-aware routing. Interference is an inherent property of wireless networks determining boundaries for spectrum reuse and directly affecting the network capacity as well as protocol performance. Estimating interference in a wireless network and circumventing its effects is not a trivial task. The amount of interference depends on many factors including the radio propagation environment, spatial node distribution, MAC protocol dynamics. Therefore, adding interference-awareness to the routing protocol decisions is challenging.

The first contribution of this thesis is a quantitative comparison of multipath routing protocols proposed for wireless multihop networks. Multipath routing represents a promising alternative to single-path routing in that it enables load balancing and resilience to route failures. We show that multipath routing outperforms single-path in networks with high node density and network load and the use of two, maximum three, paths represents the best 
tradeoff between routing overhead and performance. Nevertheless, the requirement for efficient data scheduling remains equally important for both multipath and single-path routing protocols.

The role of interference in that is critical. Therefore, much of our work addresses interference modeling. We derive an analytical model for the probability that a transmission destined to an arbitrary network node is successful in the presence of interference from other nodes in the network. Our analytical expression for the data loss probability is a function of the network density, node transmission probability, radio propagation environment, and network card hardware. We validate our interference model against experiments in a real testbed, set up for this purpose in our indoor office environment, showing good match of the experimental results with the analytical predictions.

Our work concludes with the design of an interference-aware routing metric that explicitly takes interference into account via our analytical derivation. Contrary to measurement-based models, our derivation only requires information that is locally available to the nodes, avoiding all measurement-related pitfalls. We show that its performance compares favorably with those achieved by the state-of-the-art probe-based routing metric. 


\section{Kurzfassung}

Vermaschte drahtlose Multihop-Netzwerke sind heute als alternative Netzwerk-Strukturen im Aufkommen und finden Einsatz auf Gebieten wie dem gemeinsamen Zugang zu Breitband-Internet, Überwachung medizinischer und sicherheitstechnischer Notfälle, verteiltes Backup und Multimedia-Anwendungen. Da solche Netzwerke weitgehend dezentralisiert sind und sich selbst organisieren, ist das Routing ein kritischer Faktor in Bezug auf ihre Leistungsfähigkeit und Effizienz.

Der Fokus der vorliegenden Dissertation ist das Routing unter Berücksichtigung von Interferenz. Interferenz ist eine inhärente Eigenschaft drahtloser Netzwerke, die die Wiederverwendung des Spektrums einschränkt und die Kapazität des Netzwerks als auch die Leistungsfähigkeit des Protokolls direkt beeinflusst. Die Bestimmung und Vermeidung von Interferenz in einem drahtlosen Netzwerk ist keine triviale Aufgabe. Der Umfang der Interferenz hängt von mehreren Faktoren wie der Funkwellenausbreitung, der räumlichen Knotenpunktverteilung und der Dynamik des MACProtokolls ab. Daher ist die Berücksichtigung von Interferenz in einem Routing-Protokoll eine Herausforderung.

Der erste Beitrag dieser Arbeit ist ein quantitativer Vergleich mehrerer Multipath Routing Protokolle, die für drahtlose Multihop Netzwerke verwendet werden können. Multipath Routing ist eine vielversprechende Alternative zu Singlepath-Routing, da es den Lastausgleich ermöglicht und die Ausfallsicherheit erhöht 
wird. Wir zeigen, dass Multipath-Routing in Netzwerken mit hoher Knotendichte und Belastung das Singlepath-Routing übertrifft und der Einsatz von zwei, höchstens drei Pfaden der beste Kompromiss zwischen dem Zusatzaufwand durch Routing und der Leistungsfähigkeit ist. Dennoch ist die Anforderung für effizienten Datenaustausch an Multipath und Single-path Routing Protokolle gleich hoch.

Interferenz spielt hierbei eine kritische Rolle. Ein grosser Teil unserer Arbeit ist daher der Modellierung der Interferenz gewidmet. Wir leiten ein analytisches Modell her, das die Wahrscheinlichkeit einer erfolgreichen Sendung angibt, die für einen zufälligen Netzwerkknoten bestimmt ist und unter dem Einfluss der Interferenz anderer Knoten erfolgt. Unser analytischer Ausdruck für die Wahrscheinlichkeit von Datenverlust ist eine Funktion von Netzdichte, Sendewahrscheinlichkeit eines Knotens, Funkwellenausbreitung und Eigenschaften der Netzwerkkarte. Wir validieren unser Interferenz-Modell mit Messungen in einer reellen Testumgebung, die eigens hierfür in unseren Laborräumlichkeiten aufgestellt wurde. Die Messergebnisse zeigen eine gute Übereinstimmung mit den analytischen Voraussagen.

Diese Arbeit schliesst mit der Erstellung einer Routing-Gewichtung mit expliziter Berücksichtigung der Interferenz, wie sie analytisch hergeleitet wurde. Im Gegensatz zu Modellen, die auf Messungen basieren, benötigt unsere Herleitung Informationen, die von jedem Knoten lokal erhältlich sind, und umgeht ausserdem alle Nachteile, die aus Messungen resultieren. Wir zeigen, dass es leistungsfähiger ist als andere moderne Routing-Gewichtungen, die auf Messungen basieren. 